\title{
RNA, DNA and protein concentrations in fed and starved herring Clupea harengus larvae
}

\author{
E. M. Mathers, D. F. Houlihan, L. J. Burren \\ Department of Zoology, University of Aberdeen, Tillydrone Avenue, Aberdeen AB9 2TN, Scotland, UK
}

\begin{abstract}
Herring Clupea harengus larvae were hatched and reared for $66 \mathrm{~d}$ in the laboratory to test hypotheses concerning correlations between nucleic acid concentrations and growth rates. A modified absorbance method is introduced which allowed RNA, DNA and protein to be measured on individual larvae. The amounts of RNA, DNA and protein increased per larva but no significant correlation was found between protein growth rates and RNA concentration. RNA:DNA or RNA protein. After 7 d of starvation there was a significant loss of RNA, DNA and protein only in larvae $65 \mathrm{~d}$ old. It is concluded that nucleic acid ratios, except perhaps protein to DNA ratios, are not valuable for estimating growth rates of wild larvae.
\end{abstract}

KEY WORDS: Herring · Larvae $\cdot$ RNA $\cdot$ DNA - Protein · Growth · Nutritional status

\section{INTRODUCTION}

Considerable interest has centred on the development of techniques that can assess the rate of growth of larvae and that can differentiate between fed and starved larvae. Fish larvae are subject to very high mortality rates. Several factors contributing to this have been identified: predation, the availability of suitable prey and many abiotic factors. The size at metamorphosis is less variable than the age at metamorphosis, therefore the rate of growth determines the duration of the larval stage (Chambers \& Leggett 1987) and is therefore a major factor controlling larval survival.

A main hindrance in the development of biochemical indicators of growth rate is the small size of many newly hatched marine fish larvae (1 to $3 \mathrm{mg}$ live weight). Many studies have tried to circumvent this problem by using pooled samples to produce mean estimates of the growth condition of different populations (e.g. Buckley 1979, 1984, Clemmesen 1987, Raae et al. 1988, Bergeron et al. 1991). However, within any population there is a great deal of natural variation among individuals. If a reliable technique is to be developed which can distinguish between larvae that are growing well and those that are not, then methods enabling measurements to be made on individual larvae will be important.

In juvenile and mature fish, the concentration of ribonucleic acid (RNA) in tissues or whole bodies has been widely used as a sensitive indicator of the rate of protein growth (Bulow 1987, Busacker et al. 1990), with the RNA concentration generally being expressed as the ratio of RNA to DNA concentrations (an index of the amount of RNA per cell) (Bulow 1987) or as the ratio of RNA to protein concentrations (the capacity for synthesis) (Millward et al. 1973). Measurement of nucleic acid concentrations on individual larvae has relied upon 2 different approaches. The first is based on the use of fluorescent dyes specific for nucleic acids and these have been frequently used to measure larval RNA and DNA concentrations in recent years (e.g. Clemmesen 1988, 1989, Raae et al. 1988, Westerman \& Holt 1988, Bergeron et al. 1991, Hovenkamp \& Witte 1991). In each case total nucleic acid content was measured, then DNA content was measured either after incubation with RNAse or using a DNA-specific fluorochrome. RNA concentration was subsequently estimated as the difference between these 2 measurements. In a recent comparison of 3 fluorometric methods, McGurk \& Kusser (1992) found significant differences between the methods and concluded that 
the Clemmesen (1988) method was the most reliable because errors due to fluorescence by compounds other than nucleic acids and the possibility of inhibition of RNAse by other compounds were minimised by the purification of the nucleic acids. The second method is the Schmidt-Thannhauser technique as described by Munro \& Fleck (1966,) which has been used in several larval studies (Buckley 1979, 1984, Wright \& Martin 1985, Buckley \& Lough 1987, Clemmesen 1987). It is a 2 -step procedure by which the nucleic acids are first purified and then their absorbency at $260 \mathrm{~nm}$ is recorded. The accuracy of estimating the RNA and DNA concentrations was improved by the introduction of the dual wavelength method of Munro \& Fleck (1969) in which the absorbency at $232 \mathrm{~nm}$ was used to correct for the effect of contamination from hydrolysed protein and to our knowledge this modification has not been previously applied to studies on fish larvae.

We wanted to be able to measure the RNA, DNA and protein content of individual larvae, which in effect means on the same sample. In order to do so we introduced a modification of the absorbency method. The results for RNA and DNA concentrations obtained by this modified method were compared with the fluorometric method of Clemmesen (1988). We contrasted the patterns of growth and the effects of starvation in laboratory-hatched herring larvae with respect to RNA, DNA and protein concentrations. Finally, the nucleic acid and protein concentrations of the laboratory larvae were compared with a group of similarly sized wild larvae.

\section{MATERIALS AND METHODS}

Laboratory-maintained larvae. Fertilised herring Clupea harengus eggs, adhering to perspex plates were supplied from Ballantrae Bank on the west coast of Scotland. The plates were placed in flowing, aerated seawater at $8^{\circ} \mathrm{C}$. The seawater was filtered using 75 and $10 \mu m$ pore size Schumacher filters, supplied from Scotfilters Ltd, connected in series on the inflow pipe. Two tanks, $1 \mathrm{~m}$ diameter and $50 \mathrm{~cm}$ deep, were used and were subjected to computer-controlled, simulated natural light cycles. The durations of night and day and of dawn and dusk were adjusted to be similar to the natural light conditions in Aberdeen $\left(57^{\circ} \mathrm{N}\right)$. The water temperature remained at between 8 and $10^{\circ} \mathrm{C}$ throughout the experiment.

The eggs had been fertilised on 13 March 1991 and the main hatch occurred on 30 March. On 3 April $4 \mathrm{~d}$ after hatching) larvae were provided with rotifers for feeding, and from 8 May (39 d after hatching) they were fed a mixture of rotifers and Artemia. Food was supplied daily in excess of consumption. The rotifers were supplied from growing cultures from the Marine Laboratory, Aberdeen, and the Artemia were hatched from Artemia Revolution supplied by N.T. Laboratories Ltd, Kent, England.

At intervals of 5 to $7 \mathrm{~d}$ a sample of larvae was removed from each tank before feeding. These larvae were weighed (see below), frozen in liquid nitrogen and stored at $-70^{\circ} \mathrm{C}$ before biochemical analysis. On 7 . 46 and $59 \mathrm{~d}$ after hatching, groups of larvae were transferred to a third tank and deprived of food for $7 \mathrm{~d}$ after which they were weighed and frozen as above. The length of the starvation period was determined experimentally: 3 to $4 \mathrm{~d}$ starvation showed no significant loss of weight, while by $10 \mathrm{~d}$ the mortality rate was high.

Weighing procedure. Individual larvae were gently lifted out of the seawater using a fine-mesh strainer and rinsed in distilled water. They were then damp dried to remove adhering water and transferred to a preweighed foil weigh-boat. The weight was recorded at $30 \mathrm{~s}$ intervals for $3 \mathrm{~min}$. The extrapolated weight at time zero was recorded as the wet weight of each individual (Ramsay 1991).

Wild larvae. Larvae were caught in the northern North Sea, between the Orkney Isles and Norway, during January 1990. Samples were taken using a MIKT (Methot-Isaacs-Kidd midwater trawl) net. Larvae were weighed and frozen as above and transported to Aberdeen for biochemical analysis.

Wet weight:dry weight relationships. Individual larvae were placed on preweighed pieces of foil and dried to constant weight at $50^{\circ} \mathrm{C}$. Larvae of varying ages were selected to provide as wide a weight range as possible.

Estimation of growth rate. Individual growth rates, expressed as the rate of protein growth during the experiment, were calculated using the formula of Wootton (1990):

$$
k_{\mathrm{g}}\left(\% \mathrm{~d}^{-1}\right)=\frac{\left(\ln W_{2}-\ln W_{1}\right) \times 100}{t}
$$

where $W_{1}=$ mean protein content of the larvae at the previous sampling time; $W_{2}=$ final individual protein content at the sampling time; and $t=$ time in days between sampling times.

Measurement of RNA, DNA and protein concentrations. - Preparation of samples for analysis: Preparation of the larvae for nucleic acid assay was similar to that described in Munro \& Fleck (1966) with modification for small quantities of tissue. Individual larvae were homogenised in $400 \mu \mathrm{l}$ of $0.2 \mathrm{M}$ perchloric acid (PCA) using a polytron homogeniser fitted with a $7 \mathrm{~mm}$ diameter probe (the probe tip was washed with $200 \mu \mathrm{l}$ of $0.2 \mathrm{M} \mathrm{PCA}$ ). The homogenate was centrifuged at 
$6000 \mathrm{rpm}(2000 \times g)$ for $10 \mathrm{~min}$, then the resulting precipitate was washed twice in $200 \mu \mathrm{l}$ of $0.2 \mathrm{M}$ PCA. The pellet was then suspended in $450 \mu$ dist. $\mathrm{H}_{2} \mathrm{O}$, and 50 $\mu l$ of $3 \mathrm{M} \mathrm{NaOH}$ was added. This was then incubated at $37^{\circ} \mathrm{C}$ for $1 \mathrm{~h}$ to solubilise the tissue. The solution was allowed to cool, then $110 \mu$ l was removed and kept for measuring total protein content. Proteins were then precipitated by the addition of $86.7 \mu \mathrm{l}$ of $20 \%$ PCA to the remaining $390 \mu$ of sample, and centrifuged at $6000 \mathrm{rpm}$ for $10 \mathrm{~min}$. The supernatant contained the RNA fraction which was quantified immediately. The precipitate was washed twice in $200 \mu \mathrm{l}$ of $0.2 \mathrm{M} \mathrm{PCA}$, then resuspended in $500 \mu$ l of $0.6 \mathrm{M} \mathrm{PCA}$ and incubated at $70^{\circ} \mathrm{C}$ for $30 \mathrm{~min}$ to release the DNA. The sample was cooled on ice, then centrifuged at $6000 \mathrm{rpm}$ for 10 min, and the DNA content was quantified immediately from this supernatant.

- Quantification of nucleic acid and protein concentrations: Total RNA and DNA were quantified using the dual wavelength method (Munro \& Fleck 1969, Ashford \& Pain 1986). Results were expressed as $\mu \mathrm{g}$ nucleic acid $\mathrm{mg}^{-1}$ dry wt and as the ratio of RNA to DNA concentrations. Initial experiments showed recoveries of $90.55 \pm 0.35 \%$ for RNA and $87.49 \pm 0.40 \%$ for DNA when $10 \mu \mathrm{g}$ standard samples were added to between 100 and $120 \mu \mathrm{g}$ dry wt of gill tissue (Mathers et al. 1993). Protein concentration was determined using the method of Lowry et al. (1951) with bovine serum albumin as a standard. Results are expressed as mg protein $\mathrm{g}^{-1} \mathrm{dry}$ wt and as the ratios of RNA to protein, and of protein to DNA concentrations.

- Comparison of methodologies: RNA and DNA concentrations were also determined using the fluorescence method as described by Clemmesen (1988) for individual larvae. Standard curves were prepared using calf thymus DNA (type 1, Sigma) and yeast RNA (type IV, Sigma), and the nucleic acid concentrations were determined spectrophotometrically. The first set of comparisons was made for 5 groups of fed larvae ( 7 , $10,28,46$ and 53 d after hatching) and 2 groups of larvae that had been starved for $7 \mathrm{~d}$ (12 and $52 \mathrm{~d}$ after hatching), with analysis being made on individual larvae. The second set of comparisons was made on $66 \mathrm{~d}$ larvae that were cut in half longitudinally (along the dorso-ventral axis) with each half being analysed separately using both methods.

Statistics. Comparisons between groups of fish were made using analysis of variance, Student's $t$-test and the Newman-Keuls multiple range test as appropriate, with the 5\% level of significance being used throughout (Zar 1984). Least-squares linear regression or stepwise regression analyses were used as appropriate.

\section{RESULTS}

\section{Relationships between wet and dry body weight}

Significant correlations were found between the wet weight and dry weight in both fed and starved groups of larvae (Table 1). Analysis of covariance showed that the slopes of the 2 lines were not significantly different, but that the elevations were $(p<0.001)$ indicating that the starved larvae had a higher water content. These relationships were subsequently used to express all laboratory-based nucleic acid and protein concentrations in terms of dry weight.

\section{Nucleic acid measurement: a comparison of methodologies}

Whole body RNA and DNA concentrations were measured on parallel samples for 5 different ages of fed larvae and 2 ages of starved larvae using the 2 different methods. In the majority of comparisons there was no significant difference in either RNA or DNA measurement between the 2 methods (Table 2). The differences that did occur were in larvae aged less than $12 \mathrm{~d}$ after hatching (i.e. dry weight of $\leq 200 \mu \mathrm{g}$ ) when the RNA values were higher and the DNA values lower using the dual wavelength method compared to the fluorescence method. In larger larvae (66 d after hatching, dry weight 1.8 to $2.2 \mathrm{mg}$ ), which were cut in half with one half being assayed by each method, there were no significant differences between the 2 methods (Table 2).

\section{Patterns of growth of larvae}

Over a period of $66 \mathrm{~d}$ after hatching, the fed larvae were seen to gain weight (Fig. 1A), with weight increase being slow at first and more rapid from Day 35 onwards. Each starved group had a mean weight that was significantly lower than fed larvae sampled simultaneously $(\mathrm{p}<0.01)$.

The total protein content ( $\mathrm{ug}$ larva ${ }^{-1}$ ) of the fed larvae increased in parallel to dry weight (mg) (Fig. 1A)

Table 1. Clupea harengus. Wet weight to dry weight relationships for fed and starved larvae. All weights are expressed in $\mathrm{mg}$

\begin{tabular}{|lcccc|}
\hline Status & Regression & $n$ & $r$ & $p$ \\
\hline Fed & Dry wt $=0.135$ Wet wt -0.026 & 49 & 0.973 & $<0.001$ \\
Starved & Dry wt $=0.135$ Wet wt -0.064 & 45 & 0.910 & $<0.001$ \\
\hline
\end{tabular}


Table 2. Clupea harengus. Comparison of nucleic acid measurements made using our modification of the dual wavelength method and the fluorescence method. Measurements were made on individual larvae, except at age $66 \mathrm{~d}$ after hatching where measurements were made on half larvae, one half being analyzed by each method. Values for RNA, DNA and RNA:DNA are given as means \pm SE. Method 1: dual wavelength method; Method 2: fluorescence method; "means are significantly different $(p<0.05)$

\begin{tabular}{|c|c|c|c|c|c|c|c|c|c|}
\hline \multirow{2}{*}{$\begin{array}{l}\text { Age } \\
\text { (d) }\end{array}$} & \multirow{2}{*}{ Status } & \multirow{2}{*}{$\begin{array}{c}\mathrm{n} \\
\text { Meth. } 1\end{array}$} & \multirow{2}{*}{$\begin{array}{c}\mathrm{n} \\
\text { Meth. } 2\end{array}$} & \multicolumn{2}{|c|}{ RNA $\left(\mu g \mathrm{mg}^{-1}\right.$ dry wt) } & \multicolumn{2}{|c|}{ DNA ( $\mu g \mathrm{mg}^{-1}$ dry $\left.w t\right)$} & \multicolumn{2}{|c|}{ RNA:DNA (mg mg $\left.{ }^{-1}\right)$} \\
\hline & & & & Method 1 & Method 2 & Method 1 & Method 2 & Method 1 & Method 2 \\
\hline \multicolumn{10}{|c|}{ Measurements on whole larvae } \\
\hline 7 & Fed & 6 & 8 & $23.66 \pm 0.70$ & $\cdot 11.93 \pm 0.35$ & $4.15 \pm 0.11$ & $4.41 \pm 0.14$ & $5.84 \pm 0.06$ & $2.76 \pm 0.04$ \\
\hline 10 & Fed & 5 & 5 & $29.38 \pm 2.16$ & $\cdot 14.16 \pm 1.13$ & $4.42 \pm 0.13$ & $6.87 \pm 0.04$ & $6.53 \pm 0.15$ & - $2.07 \pm 0.08$ \\
\hline 12 & Starved & 5 & 5 & $83.31 \pm 2.53$ & - $36.67 \pm 2.44$ & $21.47 \pm 0.29$ & $\cdot 34.23 \pm 0.80$ & $3.85 \pm 0.04$ & - $1.12 \pm 0.03$ \\
\hline 28 & Fed & 6 & 7 & $24.30 \pm 1.79$ & $25.61 \pm 1.42$ & $4.40 \pm 0.25$ & $4.19 \pm 0.11$ & $5.75 \pm 0.08$ & $5.39 \pm 0.11$ \\
\hline 46 & Fed & 6 & 9 & $18.31 \pm 1.41$ & $22.43 \pm 1.52$ & $4.27 \pm 0.25$ & $4.54 \pm 0.20$ & $4.27 \pm 0.07$ & $4.79 \pm 0.10$ \\
\hline 52 & Starved & 4 & 8 & $15.26 \pm 1.69$ & - $\quad 8.62 \pm 1.01$ & $4.59 \pm 0.40$ & $5.18 \pm 0.10$ & $3.85 \pm 0.09$ & $1.87 \pm 0.10$ \\
\hline 53 & Fed & 6 & 8 & $17.25 \pm 1.00$ & $23.04 \pm 0.96$ & $3.23 \pm 0.09$ & $4.42 \pm 0.25$ & $5.57 \pm 0.08$ & $4.80 \pm 0.11$ \\
\hline \multicolumn{10}{|c|}{ Measurements on half larvae } \\
\hline 66 & Fed & 6 & 6 & $3.36 \pm 0.07$ & $3.98 \pm 0.09$ & $0.90 \pm 0.01$ & $0.65 \pm 0.01$ & $4.01 \pm 0.12$ & $4.62 \pm 0.10$ \\
\hline
\end{tabular}
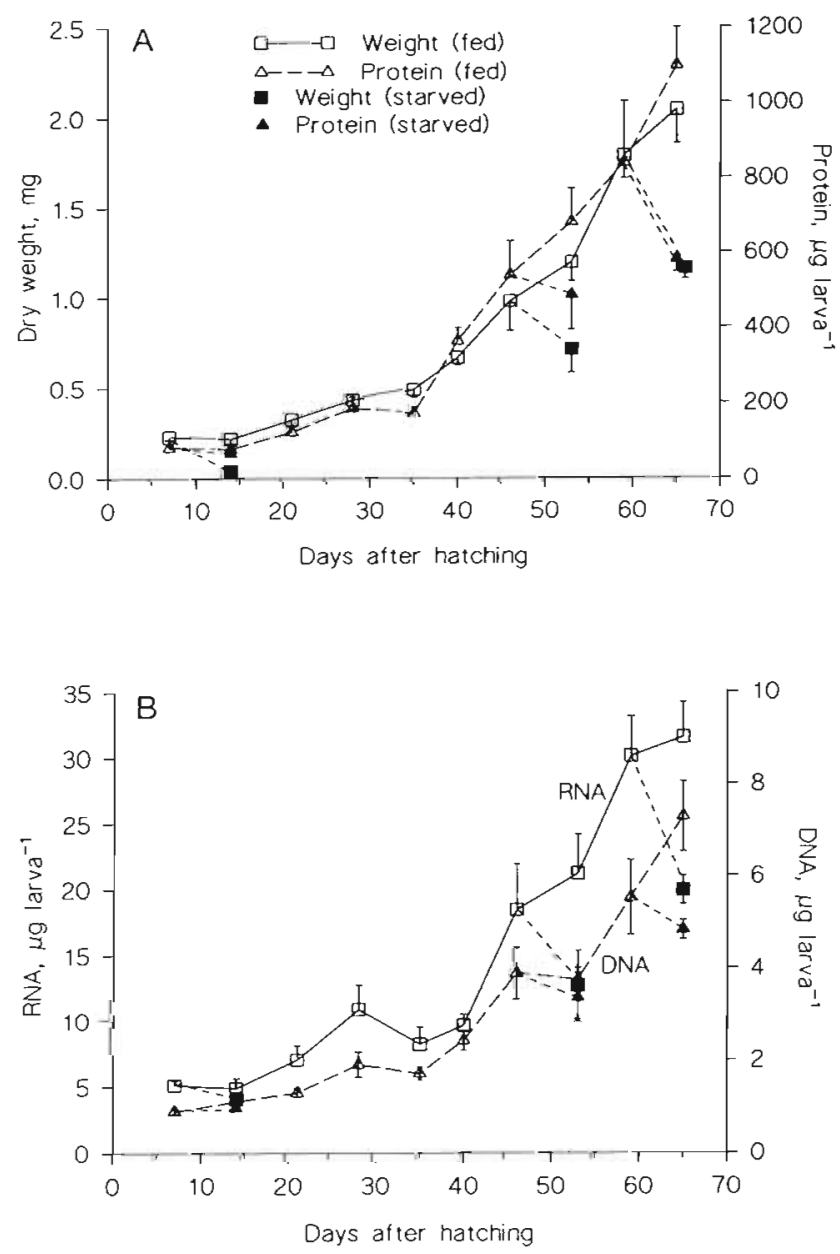

Fig. 1. Clupea harengus. Changes in (A) dry weight (mg) and total protein content $(\mu \mathrm{g})$ and $(B)$ total RNA $(\mu \mathrm{g})$ and total DNA $(\mu \mathrm{g})$ content of whole larvae over the duration of the experiment. Means $\pm \mathrm{SE}_{\mathrm{n}} \mathrm{n}=16$ to 20 individuals per sample and the relationship between them was:

$$
\begin{gathered}
\text { Protein }=-47.7+(548 \text { Dry wt }) \\
n=10, r=0.989, p<0.001
\end{gathered}
$$

Each of the starved groups had lower protein contents than the fed groups sampled simultaneously and 1 difference was significant (65 d).

Protein growth rates (PGR) were very variable with a marked increase between Days 35 and 42 (Fig. 2). The starved groups all showed rates of protein loss, which were significantly different from the protein growth rates of the fed animals sampled simultaneously (Fig. 2) at $53 \mathrm{~d}(\mathrm{p}<0.05)$ and at $65 \mathrm{~d}(\mathrm{p}<0.01)$.

As the larvae gained weight, the amount of DNA and RNA per larva also increased, indicating an increase in cell number and a parallel increase in the total amount of RNA available for protein synthesis (Fig. 1B). Starvation resulted in a loss of both DNA and RNA (Fig. 1B) which was significant at Day 65 ( $p<0.05$ for DNA, p < 0.01 for RNA).

Nucleic acid and protein concentrations were also expressed per unit of dry weight and mean RNA, DNA and protein concentrations were plotted against larval age for fed larvae (Fig. 3A). The concentrations of all 3 parameters were variable during this experiment. No significant trend in DNA concentration ( $\mu \mathrm{g} \mathrm{mg}^{-1}$ ) with age was found. Protein concentration increased significantly with larval age (Table 3).

RNA concentration remained constant until Day 30 when a sharp decline was observed after which the value remained constant at the lower level.

Mean nucleic acid and protein ratios were also plotted against larval age (Fig. 3B). RNA: DNA (an index of the amount of RNA per cell) values fluctuated between 4 and 6. RNA: protein (an index of the capacity for syn- 


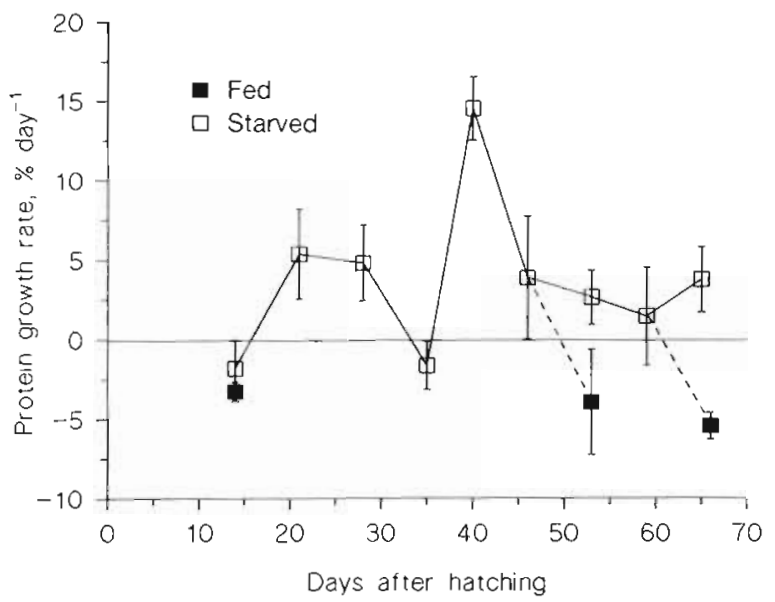

Fig. 2. Clupea harengus. Mean \pm SE larval protein growth rate over the duration of the experiment

thesis) decreased significantly with age due to changes in both RNA and protein concentrations (Table 3). Protein:DNA (an index of cell size) increased with age showing an increase in cell size because of increased protein content per cell (i.e. per unit of DNA) (Table 3). Neither RNA, RNA:DNA nor RNA: protein were significantly correlated with whole body growth rate.

\section{Comparison between fed and starved larvae}

Comparisons between fed and 7 d-starved larvae were made on 3 occasions, 14, 53 and $66 \mathrm{~d}$ after hatching. At $14 \mathrm{~d}$, highly significant differences in RNA, DNA and protein concentrations were observed between the fed and starved groups (Table 4). In the older larvae the fed-starved difference was very small or not apparent. The ratios RNA:DNA and protein:DNA were lower in the starved groups, but the only significant differences were for RNA:DNA at $53 \mathrm{~d}$ and protein:DNA at $66 \mathrm{~d}$ (Table 4). No differences were found between the fed and starved groups for RNA:protein. Dry weight expressed as a percentage of wet weight showed at each age that the starved larvae had a significantly higher water content than fed larvae. It is also worth noting that at $14 \mathrm{~d}$ that difference was significantly greater than at 53 or $66 \mathrm{~d}$.

\section{Comparison between laboratory and wild larvae}

The wild larvae had a much greater weight range than those reared in the laboratory and therefore comparison of biochemical parameters was restricted to individuals weighing 5 to $15 \mathrm{mg}$ wet wt. No significant differences in RNA or protein concentration were
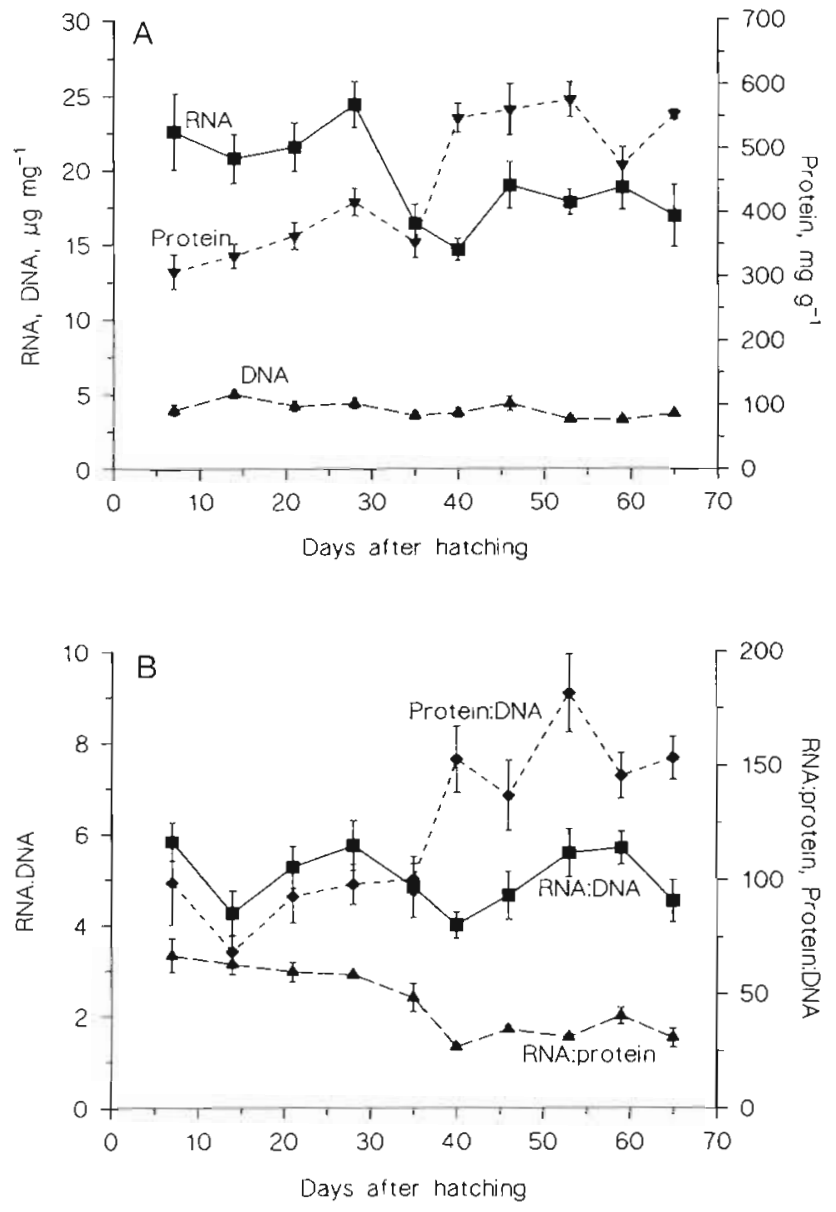

Fig. 3. Clupea harengus. Variation in (A) the concentrations of RNA ( $\mu \mathrm{g} \mathrm{mg}^{-1}$ dry wt), DNA ( $\mu \mathrm{g} \mathrm{mg}^{-1}$ dry $w \mathrm{t}$ ), and protein ( $\mathrm{mg} \mathrm{g^{-1 }}$ dry wt) and (B) the ratios of RNA:DNA (mg $\mathrm{mg}^{-1}$ ), RNA: protein $\left(\mu \mathrm{g} \mathrm{mg}^{-1}\right)$ and protein:DNA $\left(\mathrm{mg} \mathrm{mg}^{-1}\right)$ with age of larva. Means $\pm \mathrm{SE}$

found (Fig. 4). The significantly higher concentrations of DNA in the wild larvae indicated a higher cell density possibly associated with a particular developmental stage (Westerman \& Holt 1988). This difference in DNA concentration between the wild and laboratory larvae is also reflected in significantly lower RNA:DNA and protein:DNA ratios of the wild larvae.

Table 3. Clupea harengus. Relationships between protein concentration (mg g $\left.{ }^{-1} \mathrm{DW}\right)$, RNA:protein $\left(\mu \mathrm{g} \mathrm{mg}^{-1}\right.$ ), protein: DNA ( $\mathrm{mg} \mathrm{mg}^{-1}$ ) and larval age (days after hatching) for fed larvae

\begin{tabular}{|lcccc|}
\hline Parameter $(Y)$ & Regression & $\mathrm{n}$ & $\mathrm{r}$ & $\mathrm{p}$ \\
\hline Protein & $36.7+(0.568 \mathrm{Age})$ & 10 & 0.837 & $<0.01$ \\
RNA:protein & $71.0-(0.679 \mathrm{Age})$ & 10 & 0.872 & $<0.001$ \\
Protein:DNA & $66.0+(1.55 \mathrm{Age})$ & 10 & 0.836 & $<0.01$ \\
\hline
\end{tabular}


Table 4. Clupea harengus. Mean values \pm SE for wet weight, dry weight, RNA, DNA and protein concentrations and ratios for fed and $7 \mathrm{~d}$-starved larvae at 3 different times after hatching. Asterisks indicate significance of the difference between fed and starved larvae at each age $(\cdots p<0.001, \cdots p<0.01, \cdots p<0.05)$; letter indicates significance of the difference between ages, for fed and starved larvae (different letters indicate significant difference)

\begin{tabular}{|c|c|c|c|c|}
\hline \multirow[t]{2}{*}{ Parameter } & \multirow[t]{2}{*}{ Status } & \multicolumn{3}{|c|}{ Age of larvae (days after hatching) } \\
\hline & & 14 & 53 & 66 \\
\hline $\mathrm{n}$ & $\begin{array}{l}\text { Fed } \\
\text { Starved }\end{array}$ & $\begin{array}{l}8 \\
6\end{array}$ & $\begin{array}{l}8 \\
8\end{array}$ & $\begin{array}{l}8 \\
8\end{array}$ \\
\hline Wet weight (mg) & $\begin{array}{l}\text { Fed } \\
\text { Starved }\end{array}$ & $\begin{array}{l}1.795 \pm 0.180^{\mathrm{a}} \\
1.555 \pm 0.028^{\mathrm{a}}\end{array}$ & $\begin{array}{l}9.02 \pm 0.76^{\circ b} \\
5.99 \pm 0.85^{b}\end{array}$ & $\begin{aligned} 15.23 & \pm 1.40^{\circ} c \\
9.00 & \pm 0.37^{\circ}\end{aligned}$ \\
\hline Dry weight (mg) & $\begin{array}{l}\text { Fed } \\
\text { Starved }\end{array}$ & $\begin{array}{l}0.217 \pm 0.025^{\cdots a} \\
0.039 \pm 0.004^{a}\end{array}$ & $\begin{array}{l}1.192 \pm 0.100^{\circ} \mathrm{b} \\
0.709 \pm 0.130^{b}\end{array}$ & $\begin{array}{l}2.043 \pm 0.190^{\cdots} \\
1.044 \pm 0.056^{\mathrm{b}}\end{array}$ \\
\hline Dry weight (\% wet wt) & $\begin{array}{l}\text { Fed } \\
\text { Starved }\end{array}$ & $\begin{array}{c}11.96 \pm 0.12 \cdots \mathrm{d} \\
2.51 \pm 0.23^{\mathrm{d}}\end{array}$ & $\begin{array}{l}13.20 \pm 0.02 \cdot^{\circ} b \\
11.34 \pm 0.53^{b}\end{array}$ & $\begin{array}{l}13.31 \pm 0.03^{\cdot b} \\
12.91 \pm 0.10^{c}\end{array}$ \\
\hline RNA ( $\mu g \mathrm{mg}^{-1}$ dry wt) & $\begin{array}{l}\text { Fed } \\
\text { Starved }\end{array}$ & $\begin{aligned} 21.87 & \pm 1.63 \cdots \text { a } \\
109.93 & \pm 11.84^{\mathrm{d}}\end{aligned}$ & $\begin{array}{l}17.31 \pm 0.83^{\mathrm{d}} \\
17.98 \pm 1.66^{\mathrm{b}}\end{array}$ & $\begin{array}{l}16.39 \pm 2.04^{\mathrm{d}} \\
17.17 \pm 0.57^{\mathrm{b}}\end{array}$ \\
\hline DNA ( $\mu g \mathrm{mg}^{-1}$ dry wt) & $\begin{array}{l}\text { Fed } \\
\text { Starved }\end{array}$ & $\begin{aligned} 5.32 & \pm 0.33 \cdots \\
25.85 & \pm 2.18^{d}\end{aligned}$ & $\begin{array}{l}3.23 \pm 0.24 \cdots a \\
5.04 \pm 0.47^{b}\end{array}$ & $\begin{array}{l}3.57 \pm 0.16^{\circ} \circ \\
4.24 \pm 0.23^{\circ}\end{array}$ \\
\hline Protein ( $\mathrm{mg} \mathrm{g}^{-1} \mathrm{dry} w \mathrm{t}$ ) & $\begin{array}{l}\text { Fed } \\
\text { Starved }\end{array}$ & $\begin{aligned} 349.9 & \pm 18.1^{\cdots a} \mathrm{a}, \mathrm{c} \\
1752.2 & \pm 178.3^{\circ}\end{aligned}$ & $\begin{array}{l}560.3 \pm 26.3^{\circ b} \\
682.9 \pm 31.7^{b}\end{array}$ & $\begin{array}{l}536.2 \pm 7.2^{b . c} \\
500.9 \pm 22.7^{b}\end{array}$ \\
\hline RNA:DNA & $\begin{array}{l}\text { Fed } \\
\text { Starved }\end{array}$ & $\begin{array}{l}4.27 \pm 0.49^{\mathrm{a}} \\
4.25 \pm 0.23^{\mathrm{d}}\end{array}$ & $\begin{array}{l}5.59 \pm 0.53^{\circ}{ }^{\mathrm{d}} \\
3.75 \pm 0.53^{\mathrm{d}}\end{array}$ & $\begin{array}{l}4.54 \pm 0.46^{\circ} \\
4.10 \pm 0.16^{\circ}\end{array}$ \\
\hline RNA: protein & $\begin{array}{l}\text { Fed } \\
\text { Starved }\end{array}$ & $\begin{array}{l}63.03 \pm 4.44^{d} \\
62.92 \pm 2.35^{\mathrm{a}}\end{array}$ & $\begin{array}{l}31.11 \pm 1.37^{b} \\
26.73 \pm 2.89^{b}\end{array}$ & $\begin{array}{l}30.84 \pm 4.13^{\mathrm{b}} \\
34.50 \pm 1.00^{\mathrm{b}}\end{array}$ \\
\hline Protein:DNA & $\begin{array}{l}\text { Fed } \\
\text { Starved }\end{array}$ & $\begin{array}{l}68.5 \pm 7.0^{\mathrm{a}} \\
67.5 \pm 2.5^{\mathrm{a}}\end{array}$ & $\begin{array}{l}181.8 \pm 17.2^{\mathrm{b}} \\
142.2 \pm 11.3^{\mathrm{b}}\end{array}$ & $\begin{array}{l}153.3 \pm 9.5 \cdot \mathrm{b} \\
119.2 \pm 4.9^{\mathrm{b}}\end{array}$ \\
\hline
\end{tabular}

\section{DISCUSSION}

\section{Comparison of methodologies}

In this study a modified dual wavelength method was developed to allow the protein content of individual marine fish larvae to be measured in addition to the RNA and DNA concentrations. The method described by Clemmesen (1988) is considered to be the most reliable fluorometric method of measuring the RNA and DNA content of small samples (McGurk \& Kusser 1992) and we considered it necessary to compare this method with that described in this paper on the same type of tissue.

The results presented here showed that the differences between the 2 methods occurred with the smallest larvae (approximately $2 \mathrm{mg}$ wet wt, $0.25 \mathrm{mg}$ dry $\mathrm{wt}$ ) when RNA concentrations were significantly lower with the fluorometric method. The larger larvae showed similar values from both methods with only 1 significant difference out of 12 comparisons. It is not clear why these differences should be so marked on small samples and further development of the technique is necessary to clarify this. The absorbency method (Munro \& Fleck 1966) has previously been rejected because reliable results could not be obtained for samples of less than $0.8 \mathrm{mg}$ dry wt (Buckley 1984). Previous modifications have maintained the extraction volumes at around $2 \mathrm{ml}$, but by reducing the volume to $0.4 \mathrm{ml}$ and by employing the dual wavelength method we have had little problem in recovering RNA and DNA (Mathers et al. 1993).

\section{Nucleic acids and proteins in feeding larvae}

Growth in larvae not only involves an increase in body mass, but also many developmental changes such as unfolding of fins, establishment of exogenous feeding and bone calcification (Blaxter 1988). There is evidence that these processes are not continuous but are saltatory, i.e. they advance in spurts, and that the timing of the occurrence of these developmental events can vary with environmental conditions (Balon 1981).

Several studies have been carried out to describe behavioral and morphological patterns of growth in fish embryos and larvae (Penaz 1983, Balon 1984, Cunningham \& Balon 1985, Matsuoka 1987). However, increases in body mass associated with growth are achieved by an increase in the amount of protein present which can come about due to changes in the rates 
of protein synthesis and/or degradation or to changes in the efficiency of retention of that protein (Houlihan et al. 1993). Since the rate of protein synthesis depends on whole body or tissue RNA concentration (Houlihan 1991), then, if changes in protein synthesis follow the saltatory patterns of development, it is likely that this would be reflected in the RNA concentration

Many studies (including this one) of fish larvae have shown fluctuation in nucleic acid concentrations and ratios (Buckley 1984, Clemmesen 1987, 1989, Raae et al. 1988, Robinson \& Ware 1988) when values have been plotted against larval age. This suggests that there may be a connection between nucleic acid content and the saltatory growth theory, however parallel documentation of morphological development would be required to substantiate this.

We also found that whole body protein concentration increased markedly over the course of this experiment, and the protein:DNA ratio indicates that this was correlated with an increase in cell size. This was also observed by Fukuda et al. (1986) for Pacific herring larvae Clupea pallasi. The large increase in protein content found in the present study, however, was not supported by a similar increase in RNA concentration - in fact the RNA concentration was found to be decreasing at that time - suggesting that the larvae may be changing either the efficiency of the ribosomes in the synthesis of new proteins, or the efficiency of retention of newly synthesised proteins or a combination of both. A recent study on trout fry (Mathers et al. 1993) has shown that protein synthesis and degradation rates and the efficiency of retention of newly synthesised proteins do vary independently of whole body RNA concentration.

\section{Effects of food deprivation}

Larvae deprived of food undergo many physiological changes which affect the usefulness of biochemical measurements as indicators of nutritional status. It has been shown (Ehrlich 1974a) that starved herring larvae show increased water content and decreased carbohydrate, protein and fat contents. However, the comparison between fed and starved larvae is further complicated by changes in the same parameters with larval age or developmental stage. If we consider the wet weight to dry weight relationships determined in this study, it is evident that water content varies significantly over this age range. Highly elevated concentrations of RNA, DNA and protein expressed in terms of dry weight were observed in starved larvae aged $14 \mathrm{~d}$ after hatching compared with the older larvae in this study and also in sole Solea solea L. larvae studied by Bergeron et al. (1991). However, this may simply be

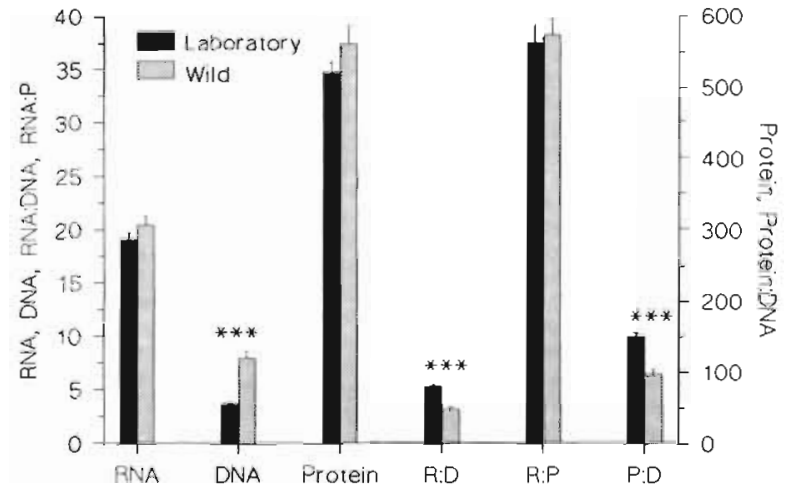

Fig. 4. Clupea harengus. Mean values $\pm \mathrm{SE}$ for the concentrations of RNA ( $\mu g \mathrm{mg}^{-1}$ dry $w \mathrm{t}$ ), DNA ( $\mu g \mathrm{mg}^{-1} \mathrm{dry} w \mathrm{w}$ ) and protein ( $m g \mathrm{~g}^{-1}$ dry wt), and the ratios of RNA:DNA (R:D) ( $\left.\mathrm{mg} \mathrm{mg}^{-1}\right)$, RNA:protein (R:P) ( $\left.\mu \mathrm{g} \mathrm{mg}^{-1}\right)$ and protein:DNA (P:D) ( $\mathrm{mg} \mathrm{mg} \mathrm{mg}^{-1}$ ) for laboratory and wild larvae of wet weight 5 to $15 \mathrm{mg}$. ". Significant difference $(\mathrm{p}<0.001)$

reflecting the fact that the difference in water content between the fed and starved groups at $14 \mathrm{~d}$ is highly significant ( $\mathrm{p}<0.001$ ).

Many studies have suggested the use of RNA:DNA ratios as a means of differentiating between fed and starved larvae and reduced RNA:DNA ratios have indeed been observed in starved groups (Bulow 1970, Wright \& Martin 1985, Clemmesen 1987, Richard et al. 1991). In this study, the approach which gave the clearest indications of starvation was to look at the RNA, DNA and protein contents per larva, which allowed comparisons to be made without the added complications of variation in carbohydrate, water and fat content. In all cases there was reduced RNA, DNA and protein content per larva for the starved groups, but the concurrent decreases in all parameters resulted in very small changes in the RNA:DNA and RNA:protein ratios which were not significant for most of the comparisons. This has also been observed for goldfish Carassius auratus ( 7 to $16 \mathrm{~g}$ ) and tilapia Oreochromis mossambicus (30 to $90 \mathrm{~g}$ ) where the RNA:protein ratio was not significantly different between fed and starved groups ( $H$. Heba unpubl.). The provision of energy during starvation in plaice Pleuronectes platessa larvae has been associated with the catabolism of carbohydrate, protein and fats (Ehrlich 1974 b) with measurable depletion of each component during the period of starvation. When the same measurements were made on herring larvae (Ehrlich 1974a), percentage changes were observed in carbohydrate and fat but not in protein, although the total protein content of the larvae was found to decrease. This is indeed what we observed in this study. 


\section{Correlations with growth rate}

RNA to DNA ratios have indicated that larvae fed high rations have higher RNA:DNA than those on low rations (Buckley 1979, Buckley et al. 1984, Clemmesen 1988, Steinhart \& Eckman 1992). Correlations with growth rate in larvae, however, have been more elusive and those reported have used pooled data sets (Buckley 1984, Buckley et al. 1984) or variation with larval age (Westerman \& Holt 1988). To our knowledge, studies on herring larvae have indicated highly variable values for RNA:DNA (Clemmesen 1989), and although measurable differences have been recorded between fed and starved larvae (Clemmesen 1987, 1989), no specific correlation with growth rate has been found. This study also has found no significant correlation between RNA concentration and protein growth rate.

\section{Comparison of laboratory and wild groups}

Assessment of the nutritional condition of wild stocks of larvae has been of considerable interest for some time. Initial studies were centred around morphological and behavioral differences between groups of wild and laboratory fish (Blaxter 1975). Recently there have been some comparisons of nucleic acid contents of marine fish larvae which suggest that there is a greater variability in RNA:DNA ratios in wild larvae as compared to laboratory reared larvae (Clemmesen 1989) and that wild larvae gain weight more quickly (Raae et al. 1988).

In this study we compared laboratory reared larvae with similarly sized larvae from the North Sea with particular reference to the nucleic acid and protein contents of those larvae. In this case the only significant difference observed between the 2 groups was DNA concentration (an index of cell number), which indicated that the wild larvae contained more cells per unit of weight than the laboratory larvae. The RNA concentration was not significantly different between the 2 groups, therefore the amount of RNA per cell (RNA:DNA) was significantly lower in the wild compared to the laboratory larvae. We cannot say whether this difference in RNA:DNA is due to the nutritional status of the larvae or whether the 2 groups of larvae were different developmental stages as described by Fukuda et al. (1986) for Pacific herring. It is likely, however that the lower concentration of RNA per cell may reflect a rate of growth in the wild larvae at the time of their capture which was lower than that observed for the laboratory reared larvae.

Acknowledgements. This project was funded by M.A.F.F. contract number CSA 1524. We thank the Marine Laboratory Aberdeen for the use of tanks, for the provision of rotifers for feeding and for assistance with collecting wild samples. We also thank Isabel Cunha and Maria Chicharo for their technical assistance with the biochemical assays

\section{LITERATURE CITED}

Ashford, A. J., Pain, V. M. (1986). Effect of diabetes on the rates of synthesis and degradation of ribosomes in rat muscle and liver in vivo. J. Biol. Chem. 261: 4059-4065

Balon, E. K. (1981). Saltatory ontogeny and altricial to precocial forms in the ontogeny of fishes. Am. Zool. 21: 573-596

Balon, E. K. (1984). Reflections on some decisive events in the early life of fishes. Trans. Am. Fish. Soc. 113: 178-185

Bergeron, J.-P., Boulhic, M., Galois, R. (1991). Effet de la déprivation de nourriture sur la teneur en ADN de la larve de sole (Solea solea L.). ICES J. mar. Sci. 48: 127-134

Blaxter, J. H. S. (1975). Reared and wild fish - how do they compare? In: Persoone, G., Jaspers, E. (eds.) Proc. 10th Eur. Mar. Biol. Symp., Vol. 1. Universa Press, Wetteren, p. 11-26

Blaxter, J. H. S. (1988). Pattern and variety in development. In: Hoar, W. S., Randall, D. J. (eds.) Fish physiology, Vol XIA. Academic Press, London, p. 1-58

Buckley, L. J. (1979). Relationships between RNA-DNA ratio, prey density and growth rate in Atlantic cod, Gadus morhua, larvae. J. Fish. Res. Bd Can. 36: 1497-1502

Buckley, L. J. (1984). RNA-DNA ratio: an index of larval fish growth in the sea. Mar. Biol. 80: 291-298

Buckley, L. J., Lough, R. G. (1987). Recent growth, biochemical composition and prey field of larval haddock (Melanogrammus aeglefinus) and Atlantic cod (Gadus morhua) on Georges Bank. Can. J. Fish. Aquat. Sci. 44 $14-25$

Buckley, L. J., Turner, S. I., Halavik, T A., Smigielski, A. S. Drew, S. M., Lawrence, G. C. (1984). Effects of temperature and food availability on growth, survival and RNA:DNA ratio of larval sand lance (Ammodytes americanus). Mar. Ecol. Prog. Ser. 15: 91-97

Bulow, F. J. (1970). RNA-DNA ratios as indicators of recent growth rates of a fish. J. Fish. Res. Bd Can. 27: 2343-2349

Bulow, F. J. (1987). RNA:DNA ratios as indicators of growth in fish: a review. In: Summerfelt, R. C., Hall, G. E. (eds.) Age and growth of fish. Iowa State University Press, Ames, p. 45-64

Busacker, G. P., Adelman, I. R., Goolish, E. M. (1990). Growth. In: Schreck, C. B., Moyle, P. B. (eds.) Methods for fish biology. American Fisheries Society, Bethesda, MD, p. 363-387

Chambers, R. C., Leggett, W. C. (1987). Size and age at metamorphosis in marine fishes: an analysis of laboratoryreared winter flounder (Pseudopleuronectes amencanus) with a review of variation in other species. Can. J. Fish. Aquat. Sci. 44: 1936-1947

Clemmesen, C. M. (1987). Laboratory studies on RNA/DNA ratios of starved and fed herring (Clupea harengus) and turbot (Scopthalamus maximus) larvae. J. Cons. int. Explor. Mer 43: 122-128

Clemmesen, C. M. (1988). A RNA and DNA fluorescence technique to evaluate the nutritional condition of individual marine fish larvae. Meeresforsch. 32: 134-143

Clemmesen, C. M. (1989). RNA/DNA ratios of laboratoryreared and wild herring larvae determined with a highly sensitive fluorescence method. J. Fish Biol. 35: 331-333

Cunningham, J. E. R., Balon, E. K. (1985). Early ontogeny of Adinia xenica (Pisces, Cyprinodontiformes): 1. The development of embryos in hiding. Environ. Biol. Fish. 14 $115-166$ 
Ehrlich, K. F. (1974a). Chemical changes during growth and starvation of herring larvae. In: Blaxter, J. H. S. (ed.) The early life history of fish. Springer-Verlag, Berlin, p. 301-323

Ehrlich, K. F. (1974b). Chemical changes during growth and starvation of larval Pleuronectes platessa. Mar. Biol. 24: $39-48$

Fukuda, M., Nakano, H., Yamamoto, K. (1986). Biochemical changes in Pacific herring during early developmental stages. Bull. Fac. Fish. Hokkaido Univ. 37: 30-37

Houlihan, D. F. (1991). Protein turnover in ectotherms and its relationship to energetics. In: Gilles, R. (ed.) Advances in comparative and environmental physiology, $\mathrm{V}_{\mathrm{ol}} \mathrm{7}$ Springer-Verlag, Berlin, p. 1-43

Houlihan, D. F., Mathers, E. M., Foster, A. (1993). Biochemical correlates of growth rate in fish. In: Rankin, J. C., Jensen, F. B. (eds.) Fish ecophysiology. Chapman and Hall, London, p. $45-71$

Hovenkamp, F., Witte, J. IJ. (1991). Growth, otolith growth and RNA/DNA ratios of larval plaice, Pleuronectes platessa, in the North Sea 1987 to 1989. Mar. Ecol. Prog. Ser. 70: 105-116

Lowry, O. H., Rosebrough, N. J., Farr, A. L., Randall, R. J. (1951). Protein measurement with Folin phenol reagent. J. Biol. Chem. 193: 265-275

Mathers, E. M., Houlihan, D. F., McCarthy, 1. (1993). Rates of growth and protein synthesis correlated with nucleic acid content in fry of rainbow trout, Oncorhynchus mykiss (Walbaum): effects of age and temperature. J. Fish Biol. 43: $245-263$

Matsuoka, M. (1987). Development of the skeletal tissues and skeletal muscles in the red sea bream. Bull. Seikai Reg. Fish. Res. Lab. 65: 1-111

McGurk, M. D., Kusser, W. C. (1992). Comparison of three methods of measuring RNA and DNA concentrations of individual Pacific herring, Clupea harengus, larvae. Can. J. Fish. Aquat. Sci. 49: 967-973

Millward, D. J., Garlick, P. J., James, W. P. T., Nnanyelugo, D. O., Ryatt, J. S. (1973). Relationship between protein

This article was submitted to the editor synthesis and RNA content in skeletal muscle. Nature 241. 204-205

Munro, H. N., Fleck, A. (1966). The determination of nucleic acids. Meth. Biochem. Anal 14: 113-176

Munro, H. N., Fleck, A. (1969). Analysis of tissue and body fluids for nitrogenous constituents. In: Munro, H. N. (ed) Mammalian protein metabolism, Vol. 3. Academic Press, New York, p. 423-525

Penaz, M. (1983). Ecomorphological laws and saltation in the early ontogeny of Salmonoidei. Folia Zool. 32: 365-373

Raae, A. J., Opstad, I., Kvenseth, P., Walther, B. Th. (1988). RNA, DNA and protein during early development in feeding and starved cod (Gadus morhua L.) larvae. Aquaculture 73: 247-259

Ramsay, N. C. (1991). The effect of pollutants on osmotic and ionic regulation of herring (Clupea harengus) embryos and larvae. Ph.D. thesis, Aberdeen University

Richard, P., Bergeron, J.-P., Boulhic, M., Galois, R., Ruyet, J. P. (1991). Effect of starvation on RNA, DNA and protein content of laboratory-reared larvae and juveniles of Solea solea. Mar. Ecol. Prog. Ser. 72: 69-77

Robinson, S. M. C., Ware, D. M. (1988). Ontogenetic development of growth rates in larval Pacific herring, Clupea harengus pallasi, measured with RNA-DNA ratios in the strait of Georgia, British Columbia. Can. J. Fish. Aquat. Sci. 45: $1422-1429$

Steinhart, M., Eckmann, R. (1992). Evaluating the nutritional condition of individual whitefish (Coregonus spp.) larvae by the RNA/DNA ratio. J. Fish Biol. 40:791-799

Westerman, M. E., Holt, G. J. (1988). The RNA-DNA ratiomeasurement of nucleic acids in larval Sciaenops ocellatus. Contr. mar. Sci. 30 (suppl.): 117-124

Wootton, R. J. (1990). The ecology of teleost fishes. Chapman and Hall, London

Wright, D. A., Martin, F. D. (1985). The effect of starvation on RNA:DNA ratios and growth of larval striped bass, Morone saxatalis. J. Fish Biol. 27: 479-485

Zar, J. H. (1984). Biostatistical analysis, 2nd edn. PrenticeHall, Englewood Cliffs, NJ

Manuscript first received: August 19, 1993

Revised version accepted: February 17, 1994 